\title{
PKM PERANGKAT PEMERINTAHAN DESA WUWUK BARAT KECAMATAN TARERAN KABUPATEN MINAHASA SELATAN
}

\author{
Sjuul Juliana Lendo \\ Universitas Negeri Manado \\ lendo.sjuul@gmail.com
}

\begin{abstract}
Abstrak
Program Kegiatan Pengabdian Kepada Masyarakat yang bertajuk "PKM Perangkat Pemerintahan Desa Wuwuk Barat" ini telah melaksanakan kegiatan pelatihan bahasa Indonesia Praktis bagi perangkat pemerintahan desa Wuwuk Barat, yang terdiri dari Hukum Tua, Kepala Jaga, Meweteng, Kepala Urusan/Seksi, sebagai penanggung jawab pemerintahan desa Wuwuk Barat yang terdiri atas lima jaga, jaga 1-5. Tujuan kegiatan ini adalah untuk meningkatkan kualitas sumber daya manusia, dalam hal ini perangkat pemerintahan, agar mereka memiliki kemampuan yang memadai dalam menggunakan bahasa Indonesia yang baik dan benar. Pelatihan ini juga telah dijadikan sarana untuk pembinaan, pengembangan dan pelestarian bahasa Indonesia, sekaligus sebagai sarana untuk menumbuhkan sikap positif tehadap bahasa Indonesia, sehingga perangkat pemerintahan dapat menjadi contoh bagi masyarakat dalam hal memiliki rasa bangga, setia dan mau menggunakan bahasa Indonesia dengan baik dan benar. Metode yang digunakan dalam pelatihan ini adalah metode eklektik, yaitu sebuh metode yang mencampurkan beberapa metode pengajaran bahasa. Metode ini diterapkan berbasis pedekatan komunikatif, kontekstual dan whole teaching. Target khusus kegiatan ini berupa pelatihan bahasa Indonesia telah berjalan dengan baik dan telah menghasilkan luaran berupa artikel ilmiah yang siap diterbitkan dalam jurnal berISSN dan segera akan didaftarkan untuk perolehan HAKI. Kegiatan pelatihan ini selanjutnya dapat menjadi pintu masuk bagi kegiatan-kegiatan pengabdian Unima pada masyarakat lainnya, melalui LPPM Unima, guna merespons berbagai kebutuhan dan permasalan dalam masyarakat.
\end{abstract}

Kata-kata kunci: komunikatif, kontekstual, whole teaching 


\section{PENDAHULUAN}

\section{A. Analisis Situasi}

Peningkatan kualitas sumber daya manusia adalah hal yang perlu mendapatkan perhatian dalam sebuah proses pembangunan. Faktor manusia merupakan subyek sekaligus obyek pembangunan. Dapat dipastikan bahwa terdapat hubungan yang sangat erat antara kualitas sumber daya manusia dengan kualitas pembangunan. Semakin baik kualitas sumber daya manusia, semakin baik pula kualitas pembangunan. Karena itu upaya-upaya peningkatan kualitas manusia perlu digalakkan dan ditingkatkan secara berkelanjutan.

Perangkat pemerintahan desa adalah bagian dari sumber daya manusia Indonesia yang memegang peranan penting dalam rangka pembangunan Indonesia seutuhnya. Keberhasilan negara salah satunya ditentukan oleh keberhasilan desadesa sebagai basis pembangunan nasional. Dalam hal inilah peran pemerintah desa menjadi sangat menentukan. Penyelenggaraan pemerintahan desa yang baik akan menentukan keberhasilan pembangunan. Perangkat pemerintahan desa adalah penyelenggara administrasi desa. Sebagai penyelenggara administrasi desa perangkat pemerintahan atau perangkat desa perlu dibekali dengan pengetahuan dan keterampilan yang dapat mendukung pelaksanaan tugas kerja mereka.
Kemampuan berkomunikasi adalah salah satu hal yang perlu dimiliki oleh perangkat desa. Kenyataannya tidak semua perangkat desa dapat berkomunikasi dengan bahasa yang baik, dalam hal ini bahasa Indonesia sebagai bahasa negara, karena tidak semua perangkat desa memiliki latar belakang pendidikan yang memadai dalam hal berkomunikasi atau menggunakan bahasa dengan baik dan benar. Tidak jarang, ketika berpidato atau menyampaikan sambutan ataupun menyampaikan pengumuman di depan masyarakat, banyak aparat desa yang menjadi bahan tertawaan karena tidak mampu menggunakan bahasa Indonesia dengan baik dan benar. Demikian juga dengan kemampuan surat-menyurat dan kegiatan administrasi lainnya, perangkat pemerintahan desa masih sangat perlu untuk belajar dan meningkatkan pengetahuan dan ketrerampilan mereka.

Demikian juga kenyataan yang ada pada perangkat pemerintahan di desa Wuwuk Barat kecamatan Tareran Kabupaten Minahasa Selatan. Berbagai kendala dalam berkomunikasi dengan menggunakan bahasa Indonesia menunjukkan bahwa aparat pemerintahan di desa ini memerlukan bantuan untuk mengatasi hal ini. Perlu ada pihak terkait yang turun tangan agar permasalahan ini dapat diatasi.

Menyikapi permasalahan yang dihadapi oleh perangkat pemerintahan di 
desa Wuwuk Barat ini, maka UNIMA sebagai lembaga pendidikan yang selalu responsif terhadap berbagai permasalahan dan kebutuhan yang ada di tengah-tengah masyarakat, melalui Lembaga Pengabdian kepada Masyarakat telah melaksanakan suatu kegiatan pengabdian kepada masyarakat, yaitu kegiatan pelatihan bahasa Indonesia praktis bagi perangkat pemerintahan desa Wuwuk Barat.

Dengan pelatihan ini perangkat pemerintahan desa Wuwuk Barat selanjutnya memiliki kemampuan berkomunikasi dan juga dapat menyelenggarakan kegiatan administrasi desa dengan menggunakan bahasa Indonesia yang baik dan benar. Kegiatan pelatihan ini sekaligus juga menjadi sarana untuk pembinaan dan pelestarian bahasa Indonesia.

\section{B. Permasalahan Mitra}

Adapun permasalahan mitra dapat dirumuskan sebagai berikut: Perangkat pemerintahan desa Wuwuk Barat Kecamatan Tareran Kabupaten Minahasa Selatan masih belum sepenuhnya dapat menggunakan bahasa Indonesia dengan baik dan benar dalam melaksanakan tugas sebagai penyelenggara administrasi dan dalam tugas-tuga kemasyarakatan lainnya.

\section{TARGET DAN LUARAN}

\section{A. Target}

Melaksanakan kegiatan pelatihan bahasa Indonesia praktis bagi perangkat pemerintahan desa Wuwuk
Barat Kecamatan Tareran kabupaten Minahasa Selatan, dengan materi mancakup keterampilan berpidato singkat, surat-menyurat dan pengenalan istilah-istilah umum yang dibutuhkan dalam pelaksanaan tugas sebagai penyelenggara administrasi.

\section{B. Luaran}

Adapun luaran yang dihasilkan melalui kegiatan pelatihan ini adalah sebuah artikel ilmiah yang siap dipublikasikan dalam jurnal ilmiah ber ISSN dan selanjutnya akan didaftarkan untuk memeperoleh HAKI.

\section{METODE PELAKSANAAN}

Metode yang digunakan dalam pelatihan bahasa Indonesia ini adalah metode eklektik atau metode campuran dari beberapa metode pengajaran bahasa dan beberapa metode pengajaran umum, seperti diskusi, tanya jawab dan penugasan. Metode eklektik ini berbasis pendekatan Kontekstual, pendekatan Komunikatif dan pendekatan Whole Languange.

Ridwan (2011:4) menyatakan, pendekatan kontekstual adalah konsep pembelajaran yang mengaitkan materi ajar dengan kebutuhan yang ada dengan situasi dan kondisi dari yang belajar bahasa, sehingga mereka dapat memahami dengan lebih baik apa yang dipelajarinya karena dekat dengan kesehariannya. Pendekatan komunikatif adalah pendekatan yang memandang bahasa sebagai sarana untuk 
berkomunikasi, bukan sebagai seperangkat kaidah untuk dihafal. Dengan pendekatan komunikatif pembelajar diarahkan untuk aktif berpartisipasi dalam proses pembelajaran.Selanjutnya pendekatan Whole Language adalah pendekatan yang berlandaskan prinsip, bahwa bahasa itu tidak terpisah-pisah, tetapi utuh dan lengkap, dimana ketika berbicara orang akan juga mendengar, bahkan sekaligus juga dapat menulis dan membaca. Dengan pendekatan Whole Language semua keterampilan berbahasa diajarkan secara terpadu atau terintegrasi.

\section{HASIL DAN LUARAN YANG DICAPAI}

Berdasarkan target yang telah ditetapkan, maka hasil yang telah dicapai dalam pelaksanaan program pengabdian kepada masyarakat ini adalah sebuah pelatihan bahasa Indonesia praktis bagi perangkat pemerintahan di desa Wuwuk Barat Kecamatan Tareran Kabupaten Minahasa Selatan. Sedangkan luaran yang telah dicapai adalah sebuah artikel yang siap untuk dipublikasikan pada jurnal ilmiah ber ISSN dan selanjutnya akan didaftarkan untuk perolehan HAKI.

Adapun materi pelatihan yang telah diberikan kepada peserta pelatihan, yang terdiri atas Hukum Tua, Kepala Jaga, Meweteng, Kepala Seksi/Urusan, dapat digambarkan sebagai berikut:

\section{Ketrampilan berpidato sederhana} dengan memperhatikan:

\section{Tata Bahasa}

Penggunaan Kalimat, yang mencakup:

- Kalimat Baku dan Kalimat Tidak Baku

Contoh: Kami menghaturkan terima kasih atas kehadirannya

(tidak baku)

Kami mengucapkan terima kasih atas kehadiran saudara

(baku)

- Ragam Baku dan Ragam Tidak Baku Contoh: Bilang dahulu dong dengan bini saya (tidak baku)

Bicarakan dahulu dengan istri saya

- Kalimat Teratur dan Kalimat Tidak Teratur

Contoh: Ini hari, kita tidak bicarakan tentang soal harga, melainkan tentang mutu barang itu (tidak baku)

Hari ini kita tidak membicarakan soal harga, tetapi soal mutu barang itu (baku)

\section{- Kalimat Efektif}

Contoh: Jika bus ini mengambil penumpang di luar agen supaya melaporkan kepada kami (tidak efektif)

Jika bus ini mengambil penumpang diluar agen, Anda diharapkan melaporkannya pada kami (efektif)

- Kalimat Bermakna Ganda 
Contoh: Tahun ini SPP mahasiswa baru dinaikkan (makna ganda, kata baru)

Tahun ini SPP mahasiswa-baru dinaikkan ( tidak ganda,baru menerangkan mahasiswa) SPP mahasiswa tahun ini baru dinaikkan (tidak ganda, baru menerangkan kata dinaikka

2. Komposisi : Komposisi adalah bentuk pengungkapan suatu gagasan yang diekspresikan dalam rangkaian kalimat. Rangkaian kalimat ini disebut paragraf atau alinea. Satu paragraf dikembangkan dari satu ide pokok yang tertuang dalam kalimat utama sebagai kalimat pembuka paragraf. Kalimat-kalimat lain sesudah kalimat utama yang adalah ide pokok paragraf disebut kalimat-kalimat penjelas. Berapa banyak kalimat penjelas yang hendak ditulis, tergantung dari wawasan penulis tentang ide pokok, jadi dapat hanya dua kalimat atau lebih dari sepuluh kalimat. Satu paragraf akan ditutup dengan satu kalimat penutup atau kalimat kesimpulan, yang biasanya mengulang atau memberi penekanan kembali tentang ide pokok, dengan formulasi bahasa yang berbeda.

\section{Penggunaan Istilah:}

Rekayasa, otonomi, otoriter, rekonsiliasi, euforia, paradigma, masyarakat madani, masyarakat marginal, status quo, klarifikasi, kondusif, modus operandi, provokator, komunitas, moratorium, kontroversi, kontroversial, demisioner, insubordinasi, anarkis, deregulasi, komplikasi, holistik, sistemik, komprehensif, postmodern, dan lainlain. Istilah-istilah ini disajikan dengan memberikan contoh-contoh kalimat.

\section{Pilihan Kata:}

Pemimpin dan Pimpinan

Masing-masing dan tiap-tiap

Menyolok dan mencolok

Jam dan pukul

Kebijakan dan kebijaksanaan

Juara dan pemenang

Suatu dan sesuatu

Sekali dan sekali-kali

Yang Terhormat dan Yang Saya Hormati

Pengangguran dan Penganggur

Pertandingan dan perlombaan

Hanya dan saja

Menanyakan dan mempertanyakan

Sudah dan telah

Kepada dan terhadap

Pekerjaan, profesi dan jabatan Pemandangan umum dan pandangan umum

Metropolitan dan megapolitan

\section{KESIMPULAN DAN SARAN}

\section{Kesimpulan}

Pelatihan bahasa Indonesia praktis bagi perangkat pemerintahan desa Wuwuk Barat ini adalah bagian dari upaya untuk 
meningkatkan kualitas sumber daya perangkat pemerintahan desa, dalam hal ini kualitas berkomunkasi dengan menggunakan bahasa Indonesia yang baik dan benar. Dengan pelatihan ini para perangkat desa Wuwuk Barat telah dibekali dengan pengetahuan tentang bagaimana berpidato atau menyampaikan pengumuman pada masyarakat, bagaimana menyelenggarakan administrasi pemerintahan dengan menggunakan pola kalimat yang benar dan pilihan kata yang tepat, bagaimana menggunakan istilahistilah yang berkaitan dengan tugas seharihari dnegan baik dan benar. Pengetahuan dan keterampilan berbahasa Indonesia sangat menunjang penyelengaraan tugas pemerintahan dari seluruh perangkat desa.

Kegiatan pelatihan bahasa Indonesia ini memang penting dilaksanakan dalam rangka pembinaan Bahasa Indonesia, agar para perangkat desa dapat melaksanakan tugas dengan menggunakan bahasa Indonesia dengan baik dan benar. Pelatihan ini setidak-tidaknya telah memberi dampak positif bagi pembinaan, pengembangan dan pelestarian bahasa Indonesia. Disamping itu juga telah memberi kontribusi bagi terbentuknya sikap positif dari perangkat pemerintahan agar mereka bangga, setia dan mau menggunakan bahasa Indonesia, sebagai bahasa persatuan bangsa dan negara Indonesia.

\section{Saran}

Kegiatan pelatihan bahasa Indonesia praktis ini baru menyentuh sebagian kecil dari pengetahuan dan keterampilan berbahasa Indonesia yang perlu dimiliki oleh perangkat desa. Karena itu disarankan untuk dilaksanakan pelatihan lanjutan agar perangkat desa semakin dapat berbahasa Indonesia yang baik dan benar.

\section{KEPUSTAKAAN}

Kemendikbud. 2011. Undang-Undang Negara RI No.24 Tahun 2009. Jakarta: Badan Pengembangan dan Pembinaan Bahasa.

Ridwan, Sakura. 2011. Metodologi Pemelajaran Bahasa. Yogyakarta: Kepel Press.

Sugono, Dendy (Penyunting Utama). 2011. Buku Praktis Bahasa Indonesia Jilid 1. Jakarta: Badan Pengembangan dan Pembinaan Bahasa Indonesia KEMENDIKBUD. 